\title{
Endocrine and metabolic factors involved in the effect of nutrition on the production of colostrum in female sheep
}

\author{
Georgett E. BANCHERO ${ }^{\mathrm{a} *}$, Raquel PEREZ ClaRIGET ${ }^{\mathrm{b}}$, Roberta BENCINI ${ }^{\mathrm{c}}$, \\ David R. LINDSAY ${ }^{\mathrm{c}}$, John T.B. MILTON ${ }^{\mathrm{c}}$, Graeme B. MARTIN ${ }^{\mathrm{c}}$

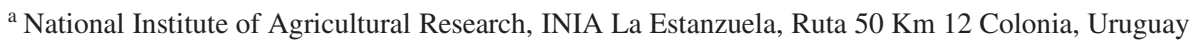 \\ ${ }^{\mathrm{b}}$ Animal and Forage Sciences Department, Faculty of Agriculture, Avda. E. Garzón 780, 12900, \\ Montevideo, Uruguay \\ ${ }^{c}$ School of Animal Biology, The University of Western Australia, Crawley 6907, Australia
}

\begin{abstract}
We investigated the physiological relationship between diet during pregnancy and colostrum production in ewes to test the hypothesis that for ewes that are in low body condition, with low fat reserves, the food supply will be the main source of energy for colostrum synthesis. To this end, we measured the amount of colostrum accumulated by ewes under two levels of nutrition. We also measured the circulating concentrations of metabolites and hormones associated with lactogenesis ( $\beta$-hydroxybutyrate, glucose, progesterone, prolactin, cortisol, growth hormone, leptin, insulin and insulin-like growth factor-I) Ewes were either under-fed at $70(n=15)$ or well-fed at $110 \%(n=10)$ of their daily metabolisable energy requirement during the last two months of pregnancy. Colostrum accumulation up to parturition was $168 \pm 48 \mathrm{~g}$ for under-fed ewes and $451 \pm 103 \mathrm{~g}$ for well-fed ewes. After birth, under-fed ewes produced less colostrum than well-fed ewes but the difference was no longer significant. The level of nutrition also influenced the plasma concentrations of hormones and metabolites related to lactogenesis. Progesterone concentrations decreased before lambing in all animals but in under-fed ewes the fall appeared to be too small to initiate the onset of colostrum production. $\beta$-hydroxybutyrate concentrations were higher in under-fed than in well-fed ewes, suggesting that the under-fed ewes were mobilising more adipose tissue but they still did not meet their ME requirements for colostrum production. We concluded that, in underfed ewes, there are insufficient nutrients for adequate lactation and the hormone regime is inappropriate for good udder development and colostrum synthesis.
\end{abstract}

udder development / lactogenesis / $\beta$-hydroxybutyrate / glucose / progesterone / prolactin / cortisol / growth hormone / leptin / insulin / insulin-like growth factor-I / lamb mortality

\section{INTRODUCTION}

Normally, well-fed ewes accumulate a large volume of colostrum in the final few days before birth and secrete milk copiously soon after lambing $[1,2]$. The process controlling lactogenesis in single-bearing Merino ewes can be studied by monitoring

* Corresponding author: banchero@inia.org.uy the changes in the concentration of mammogenic and lactogenic hormones during the last month of gestation and relating these to mammary development and production of colostrum. It is also critical to control both the quantity and quality of food consumed because they can both affect mammogenic and lactogenic hormones [2]. 
When the available nutrients fail to meet the mother's energy requirements for gestation and onset of lactogenesis, the deficit is met by mobilising adipose tissue [3] so it is desirable that the ewe has some fat reserves during the last month of gestation. However, single-bearing ewes in very good body condition may produce the same or even less colostrum as single-bearing ewes in low body condition [4] so other factors must be involved. Among the most probable causes of low production of colostrum by ewes in high body condition are a reduction in appetite [5] and the continued release of progesterone from adipose tissue [6]. Therefore, in studying how undernutrition controls lactation, it is important to avoid the confounding effects of high body condition and fat reserves. For this reason the ewes in this experiment were all in relatively low body condition (score < 2 ) with low reserves of body fat.

In this experiment, we tested the general hypothesis that maternal nutrition affects udder development and production of colostrum in single-bearing Merino ewes in two ways. First, in animals that are in low body condition, with low fat reserves, the food supply will be the main source of energy for colostrum synthesis; second, poor nutrition will affect the concentration of mammogenic and lactogenic hormones in ways that reduce tissue development and secretory output by the udder. These studies should indicate management strategies for single-bearing Merino ewes in situations when little food is available and when a short-term strategic increase in food supply to these ewes would have the highest advantage for udder development and colostrum production. We expected the endocrine patterns to provide a physiologically mechanistic basis for such strategies.

\section{MATERIALS AND METHODS}

Protocols and animal care were approved by the Animal Ethics Committee of the University of Western Australia (Ref. 99/008/E81).

\subsection{Experimental treatments}

The experiment was conducted on the campus of the University of Western Australia in July 2000 using 3-year-old Merino ewes selected from a flock inseminated on a single day by laparoscopy using fresh Merino semen and kept on outdoor green pasture on the University farm. At scanning on Day 55 of pregnancy, 25 ewes were selected that were carrying single fetuses and, 80 days after artificial insemination, they were brought indoors and placed in individual pens. From Day 80 until Day 119 of pregnancy, the ewes were fed either $70 \%$ of Metabolisable Energy (ME) requirements (under-fed ewes; $n=15$ ) or $110 \%$ of ME requirements (well-fed ewes; $n=10$ ), according to the Ministry of Agriculture, Fisheries and Food [7]. From Day 80 , the ewes were fed Diet 1 containing $80 \%$ cereal chaff, $20 \%$ lupin seed (Lupinus angustifolius) and 2\% mineral mix with a calculated content (as-fed basis) of 8.7 MJ. $\mathrm{kg}^{-1} \mathrm{ME}$ and $12 \%$ Crude Protein (CP). Over 5 days starting on Day 120, the ewes were introduced to a more concentrated diet (Diet 2) containing 48\% cereal chaff, $25 \%$ lupin seed, $25 \%$ barley grain and $2 \%$ mineral mix with a calculated $9.8 \mathrm{MJ} \cdot \mathrm{kg}^{-1}$ ME and 14\% CP (as-fed basis). The ewes were fed Diet 2 from Day 120 through to lambing. The quantity of each diet fed to the ewes in each treatment is shown in Table I. One day after birth, ewes from both groups were offered Diet 2 ad libitum. Water was available ad libitum at all times.

\subsection{Feeding and feed intake}

During the experimental period, the diet was prepared once a week according to the requirements for that week of gestation. 
Table I. Feeding regime for the ewes during the experiment.

\begin{tabular}{lllll}
\hline $\begin{array}{l}\text { Duration of feeding } \\
\text { (day of pregnancy) }\end{array}$ & $110 \%$ ME diet & & $70 \%$ ME diet & \\
\cline { 2 - 5 } & $\begin{array}{l}\text { Energy } \\
\text { MJ/head }\end{array}$ & $\begin{array}{l}\text { Diet } \\
\text { (g/kgLW }\end{array}$ & Energy MJ/head & $\begin{array}{l}\text { Diet } \\
\left(\mathrm{g} / \mathrm{kgLW}^{0.75}\right)\end{array}$ \\
\hline 86 to 106 & 7.2 & 40.0 & 4.6 & 25.5 \\
107 to 112 & 7.6 & 45.0 & 4.9 & 25.5 \\
113 to 119 & 8.0 & 47.5 & 5.1 & 30.0 \\
120 to 126 & 8.5 & 50.0 & 5.4 & 32.0 \\
127 to 133 & 9.0 & 49.0 & 5.7 & 31.0 \\
134 to 140 & 9.5 & 51.5 & 6.0 & 32.5 \\
141 to 147 & 10.0 & 54.5 & 6.4 & 34.5 \\
148 up to birth & 10.6 & 57.5 & 6.7 & 36.5 \\
\hline
\end{tabular}

The ewes were fed the requisite quantity of diet based on their metabolic body weight at $10.00 \mathrm{~h}$ each morning after blood sampling. The feed refusals for each ewe were weighed and recorded daily.

\subsection{Live weight and body condition}

Body weight and body condition were recorded once a week from Day 72 of pregnancy until lambing. During the period in the animal house, body weights and condition scores were recorded at 09:00 $\mathrm{h}$ after the ewes were bled and before they received their daily ration.

\subsection{Udder measures, production of colostrum and colostrum composition}

The volume of the udder was calculated by the formula of Bencini and Purvis [8] using the measurements made once per week from Day 125 of pregnancy to Day 140 and then every third day until birth. The full volume of the udder at lambing was calculated from its linear dimensions and the empty volume was obtained by subtracting the amount of colostrum that was expressed from the udder at birth.

Towards lambing, the ewes were observed $24 \mathrm{~h}$ per day so that, immediately after lambing, the udder volume and colostrum accumulated could be measured. Immediately after lambing, ewes were injected intramuscularly with 5 IU of oxytocin (Oxytocin ${ }^{\mathrm{TM}}$ Heriot Agvet Pty. Ltd., Australia) and one half of the udder was completely hand-milked, after which the teat was covered with tape to prevent sucking. The other teat was left uncovered for the lamb to suck. The colostrum collected was weighed and samples were mixed with a preservative and stored at $4{ }^{\circ} \mathrm{C}$ for subsequent analysis. This milking process was repeated at 3,6 and $10 \mathrm{~h}$ after lambing. The colostrum removed by milking at lambing, was considered to represent prenatal accumulation and subsequent yields were considered to represent the quantities secreted since the previous milking. All colostrum and milk samples were warmed to $40{ }^{\circ} \mathrm{C}$ in a water bath and diluted with deionised water (1:1, 1:4 or 1:8 by weight, depending on viscosity) and then analysed for fat, lactose and protein content using a Milkoscan (133 Foss Electric Denmark).

\subsection{Blood sampling}

Jugular blood was sampled by venipuncture immediately before feeding at $08.00 \mathrm{~h}$ on Days $-30,-23,-16,-9,-5$, $-4,-3,-2,-1$ relative to birth, at lambing and 1 and $18 \mathrm{~h}$ after birth. Glucose was 
immediately measured using a single drop of whole blood with a blood glucose meter and sensor electrodes (MediSense, Bedford, Massachusetts, USA). The blood samples were then chilled to $4{ }^{\circ} \mathrm{C}$ and centrifuged within one hour to separate the plasma which was poured equally into two plastic tubes and stored at $-20{ }^{\circ} \mathrm{C}$ until analysis.

\subsection{Hormone and metabolite assays}

Plasma concentrations of $\beta$-hydroxybutyrate $(\beta-\mathrm{OHB})$, urea and leptin were measured, and along with blood glucose values, were used to determine whether the food supply or body tissue was the main source of energy for colostrum synthesis. Plasma concentrations of progesterone, prolactin, GH, insulin, IGF-1 and cortisol were measured to determine whether nutrition affected the concentration of mammogenic and lactogenic hormones.

\subsection{1. $\beta$-hydroxybutyrate}

$\beta$-hydroxybutyrate $(\beta$-OHB) was measured using a spectrophotometric assay [9] and urea was measured using the enzymatic ultraviolet test, based on the urease/GLDH method, using a Roche Cobas Mira S autoanalyser (Roche, Mannheim, Germany). All samples for each metabolite were run in a single assay.

\subsubsection{Progesterone}

Progesterone was measured using a double-antibody radioimmunoassay (RIA) after extraction with hexane as previously described by Gales et al. [10] Mean concentrations in the low, medium and high quality controls were 0.94, 1.8 and $5.0 \mathrm{ng} . \mathrm{mL}^{-1}$. Intra- and inter-assay coefficients of variation were 10.7 and $22.6 \%$ and the limit of detection was 0.38 ng. $\mathrm{mL}^{-1}$.

\subsubsection{Cortisol}

Cortisol was measured in duplicate by Dextran-Coated Charcoal RIA after extraction with methylene chloride:ethanol (99:1 $\mathrm{v} / \mathrm{v}$ ) as previously described by Abraham et al. [11]. Mean concentrations in the low, medium and high quality controls were 12.2, 28.6 and 38.2 ng.mL ${ }^{-1}$. Intra- and inter-assay coefficients of variation were 6.2 and $8.3 \%$ and the limit of detection was $5.8 \mathrm{ng} . \mathrm{mL}^{-1}$.

\subsubsection{Insulin}

Insulin was measured in duplicate with the double-antibody RIA of Hales and Randle, [12] as modified by Basset and Wallace [13] and described by Tindal et al. [14]. Mean concentrations in the low, medium and high quality controls were 3.5, 6.0 and $16.6 \mu \mathrm{U} . \mathrm{mL}^{-1}$. The intra-assay coefficient of variation was $7.9 \%$ and the limit of detection was $1.42 \mu \mathrm{U} \cdot \mathrm{mL}^{-1}$.

\subsubsection{Growth hormone}

Growth hormone was measured in duplicate by RIA as described by Downing et al. [15]. Mean concentrations in the low, medium and high quality controls were 15.1, 24.6 and $49.8 \mathrm{ng} \cdot \mathrm{mL}^{-1}$. Intra-assay coefficient of variation was $9.3 \%$ and the limit of detection was 0.49 ng.mL ${ }^{-1}$.

\subsubsection{Insulin-like growth factor I (IGF-I)}

Insulin-like growth factor I (IGF-I) was measured in duplicate using the RIA method described by Gluckman et al. [16]. Mean concentration in the low quality control was 1.0 ng. $\mathrm{mL}^{-1}$ and in the high $1.24 \mathrm{ng} \cdot \mathrm{mL}^{-1}$. Intra-assay coefficient of variation was $6.15 \%$ and the limit of detection was $0.15 \mathrm{ng} \cdot \mathrm{mL}^{-1}$. 


\subsubsection{Prolactin}

Prolactin was measured in duplicate with the double antibody homologous RIA as described by Gluckman et al. [16]. Mean concentrations in the low, medium and high quality controls were $1.1,2.5$ and $3.4 \mathrm{ng} \cdot \mathrm{mL}^{-1}$. The intra-assay coefficient of variation was $8.6 \%$ and the limit of detection was $0.68 \mathrm{ng} \cdot \mathrm{mL}^{-1}$.

\subsubsection{Leptin}

Leptin was measured in duplicate with the double-antibody RIA described by Blache et al. [17]. Mean concentrations in the low, medium and high quality controls were $0.48,1.05$ and 1.26 ng.mL ${ }^{-1}$. Intraassay coefficient of variation was $4.5 \%$ and the limit of detection was $0.44 \mathrm{ng} \cdot \mathrm{mL}^{-1}$.

\subsection{Lamb birth weight and identification}

The lambs were weighed and identified soon after birth. Each lamb was allowed to suck the uncovered teat and it was also bottle-fed a supplement of ewes' colostrum when the ewe's production of colostrum was insufficient for the lamb's requirements (a secretion rate less than $45 \mathrm{~mL}$ per hour [18]).

\subsection{Statistical analyses}

The effects of nutrition on udder volume, the characteristics and volume of colostrum, ewe live weight and body condition and lamb birth weight were analysed by Least Squares Analysis of Variance using the Super ANOVA statistical programme [19]. Changes in hormone concentrations in plasma were tested by repeated measures analysis of variance using the statistical programme Genstat [20].
Udder volume

(ml)

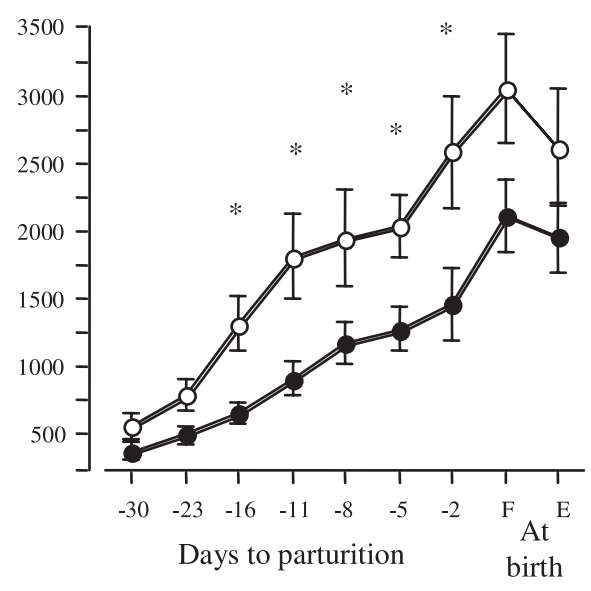

Figure 1. Udder volume at parturition in Merino ewes fed $110 \%$ (open circles) or $70 \%$ requirements (closed circles) during the last 30 days of pregnancy ( $* P<0.05$ between groups). $\mathrm{F}=$ full udder at birth before hand milking; $\mathrm{E}=$ empty udder at birth, following hand milking.

The effects were assumed to be statistically significant when the level of probability was $5 \%$ or less. All results are presented as means \pm standard errors.

\section{RESULTS}

\subsection{Udder measures and production of colostrum}

The increase in udder volume from Day -30 until lambing in the two treatment groups is shown in Figure 1. Well-fed ewes had bigger udders than under-fed ewes throughout the experimental period and the difference was significant from Day -16 up to Day -2 .

The accumulation of colostrum up to birth was 2.7-fold higher in well-fed ewes than in under-fed ewes $(P<0.05$; Tab. II). The total production of colostrum (that 
Table II. Production of colostrum (mean \pm SE) at birth and up to $10 \mathrm{~h}$ later for ewes fed 70 or $110 \%$ of ME requirement.

\begin{tabular}{llll}
\hline & $70 \%$ of ME diet & $110 \%$ of ME diet & Significance \\
\hline Amount of colostrum (g) & & \\
At birth & $168 \pm 48.1$ & $451 \pm 103$ & 0.009 \\
Birth up to $3 \mathrm{~h}$ & $132 \pm 20.8$ & $203 \pm 27.2$ & 0.06 \\
$3 \mathrm{~h}$ to $6 \mathrm{~h}$ & $122 \pm 14.3$ & $150 \pm 28.0$ & 0.33 \\
$6 \mathrm{~h}$ to $10 \mathrm{~h}$ & $170 \pm 32.5$ & $141 \pm 23.3$ & 0.53 \\
Total accumulated till 10 h after lambing & $583 \pm 80.3$ & $975 \pm 91.4$ & 0.001 \\
Total accumulated from lambing to 10 h. & $429 \pm 48.7$ & $456 \pm 57.6$ & 0.36 \\
\hline
\end{tabular}

accumulated before lambing plus that produced up to $10 \mathrm{~h}$ after lambing) was also significantly higher for well-fed ewes but this difference was almost entirely due to differences in pre-partum accumulation since the amount produced after lambing did not differ significantly between both groups.

\subsection{The constituents of the colostrum}

The percentage of solids in the colostrum decreased over the first $10 \mathrm{~h}$ in both underfed and well-fed ewes (Tab. III), mostly due to the fall in the percentage of protein which dropped by $50 \%$ after birth in both groups $(P<0.05)$. On the contrary, the percentage of fat did not change between lambing and $10 \mathrm{~h}$ after lambing. The percentage of lactose increased from birth up to $10 \mathrm{~h}$ after lambing $(P<0.05)$, during which time it almost doubled in well-fed ewes and tripled in the under-fed ewes. The percentage of fat and protein in the colostrum accumulated at birth and in the subsequent milking after lambing did not differ significantly between well-fed and underfed ewes (Tab. III). However, at birth and during the first three hours after lambing, the percentage of lactose was higher in well-fed ewes than underfed ewes. By six hours after lambing, the percentage of lactose did not differ between both groups.

At birth, well-fed ewes had double the total colostrum solids of underfed ewes
$(P<0.05$; Tab. III $)$ but this difference was mainly due to the higher volume of colostrum produced by the well-fed ewes and not due to a higher concentration of total solids. Three hours after lambing, well-fed ewes still produced more total solids in their colostrum than the underfed ewes but the difference was no longer significant $(P>0.05)$ and again the difference was due to a higher volume and not a higher concentration of solids. From $6 \mathrm{~h}$ after lambing onwards, the secretions from both groups contained similar concentrations of total solids.

\subsection{Body condition and live weight of ewes}

On Day 80 of pregnancy, both groups had an average condition score of about 1.6 (Score 1-5, [21]) (Fig. 2). After the treatments began, the well-fed ewes gained condition until birth while the under-fed ewes lost condition. From Day 112 of gestation until birth, the difference between groups was significant and, by the end of gestation, the well-fed ewes were 0.7 points of body condition more than the under-fed ewes $(P<0.05)$. The live weights of the ewes followed a similar pattern. Ewes in both groups weighed the same on Day 80 but the well-fed ewes gained weight as their pregnancy progressed while the under-fed ewes generally only maintained weight. By the end of 
Table III. Colostrum constituents at birth and during the subsequent $10 \mathrm{~h}(\% \pm \mathrm{SE})$ for ewes fed $70 \%$ or $110 \%$ of ME requirements.

\begin{tabular}{|c|c|c|c|}
\hline & $70 \%$ of $\mathrm{ME}$ diet & $110 \%$ of ME diet & Significance \\
\hline \multicolumn{4}{|l|}{ Fat } \\
\hline At birth & $14.0 \pm 1.38$ & $12.6 \pm 1.24$ & 0.51 \\
\hline Birth up to $3 \mathrm{~h}$ & $13.2 \pm 1.12$ & $15.8 \pm 1.53$ & 0.20 \\
\hline $3 \mathrm{~h}$ to $6 \mathrm{~h}$ & $12.3 \pm 1.03$ & $12.9 \pm 1.10$ & 0.71 \\
\hline $6 \mathrm{~h}$ to $10 \mathrm{~h}$ & $11.4 \pm 1.18$ & $12.1 \pm 1.80$ & 0.73 \\
\hline \multicolumn{4}{|l|}{ Protein } \\
\hline At birth & $21.5 \pm 0.89$ & $18.7 \pm 1.02$ & 0.06 \\
\hline Birth up to $3 \mathrm{~h}$ & $18.4 \pm 1.24$ & $16.0 \pm 1.65$ & 0.26 \\
\hline $3 \mathrm{~h}$ to $6 \mathrm{~h}$ & $15.8 \pm 1.41$ & $11.6 \pm 1.37$ & 0.07 \\
\hline $6 \mathrm{~h}$ to $10 \mathrm{~h}$ & $10.5 \pm 1.44$ & $8.26 \pm 1.00$ & 0.29 \\
\hline \multicolumn{4}{|l|}{ Lactose } \\
\hline At birth & $0.90 \pm 0.21$ & $2.00 \pm 0.22$ & 0.003 \\
\hline Birth up to $3 \mathrm{~h}$ & $1.46 \pm 0.29$ & $2.40 \pm 0.24$ & 0.04 \\
\hline $3 \mathrm{~h}$ to $6 \mathrm{~h}$ & $2.24 \pm 0.30$ & $3.06 \pm 0.26$ & 0.08 \\
\hline $6 \mathrm{~h}$ to $10 \mathrm{~h}$ & $3.30 \pm 0.28$ & $3.72 \pm 0.18$ & 0.32 \\
\hline \multicolumn{4}{|c|}{ Percentage of solids } \\
\hline At birth & $37.7 \pm 1.44$ & $34.6 \pm 1.90$ & 0.20 \\
\hline Birth up to $3 \mathrm{~h}$ & $34.6 \pm 1.22$ & $35.6 \pm 2.46$ & 0.68 \\
\hline $3 \mathrm{~h}$ to $6 \mathrm{~h}$ & $31.7 \pm 1.63$ & $29.0 \pm 2.00$ & 0.31 \\
\hline $6 \mathrm{~h}$ to $10 \mathrm{~h}$ & $27.2 \pm 1.83$ & $25.5 \pm 2.35$ & 0.59 \\
\hline \multicolumn{4}{|l|}{ Total solids } \\
\hline At birth & $65.3 \pm 17.4$ & $142 \pm 27.4$ & 0.02 \\
\hline Birth up to $3 \mathrm{~h}$ & $51.2 \pm 8.70$ & $73.0 \pm 10.6$ & 0.14 \\
\hline $3 \mathrm{~h}$ to $6 \mathrm{~h}$ & $40.3 \pm 5.77$ & $45.2 \pm 9.53$ & 0.65 \\
\hline $6 \mathrm{~h}$ to $10 \mathrm{~h}$ & $52.7 \pm 13.4$ & $37.8 \pm 9.05$ & 0.42 \\
\hline
\end{tabular}
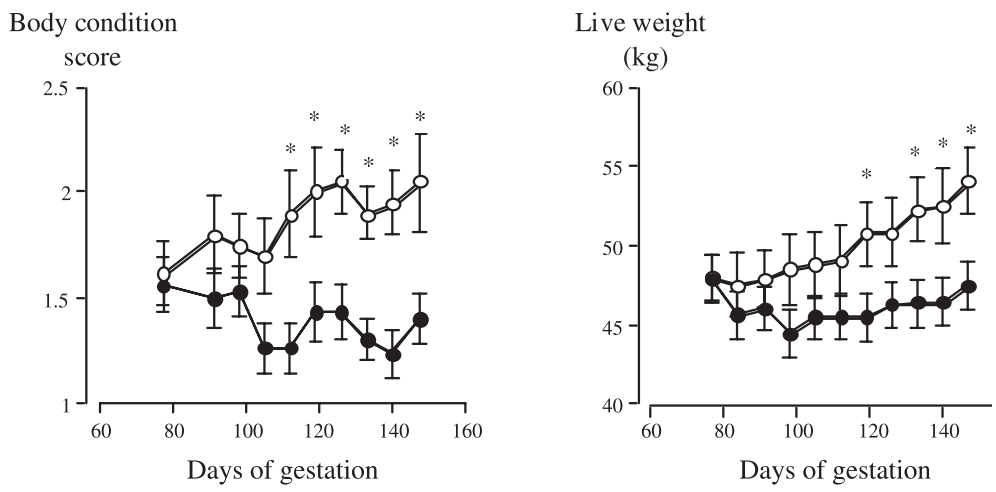

Figure 2. Body condition and live weight in Merino ewes fed $110 \%$ (open circles) or $70 \%$ of ME requirements (closed circles) during the last 60 days of pregnancy $(* P<0.05)$. 
gestation, the well-fed ewes were $7 \mathrm{~kg}$ heavier than the underfed ewes $(P<0.05)$.

\subsection{Lamb birth weights}

The lambs born to the well-fed ewes $(5.21 \pm 0.29 \mathrm{~kg})$ were about $12 \%$ heavier than those born to the under-fed ewes $(4.68 \pm 0.16 \mathrm{~kg})$ but the difference was not significant $(P=0.10)$.

\subsection{Metabolic indicators}

In both groups, plasma concentrations of glucose increased steadily during the last 30 days of pregnancy, then increased sharply around birth before returning to pre-parturient levels by $18 \mathrm{~h}$ post-partum (Fig. 3). Well-fed ewes tended to have higher concentrations than underfed ewes throughout the pre-partum period and the difference was significant from Day -30 to -9 and on Day -3 .

Plasma $\beta$-OHB concentration was higher for under-fed ewes than well-fed ewes throughout the treatment period (Fig. 3). The difference was the greatest at the start of the treatment period but then diminished and, in samples taken after birth, the differences were no longer significant.

There was no significant difference between treatments in the plasma concentrations of urea (Fig. 4). The values remained low during the first two weeks, increased around Days -10 to -5 , then decreased till $1 \mathrm{~h}$ after birth. The apparent increase at $18 \mathrm{~h}$ after birth in the well-fed animals was not significant.

Plasma leptin concentrations were the same for both groups on Day -30 (Fig. 4) but, in well-fed ewes, the leptin concentration increased immediately after the dietary treatments began. High values were maintained up to Day -5 after which they decreased steadily until birth. In underfed ewes, leptin concentrations remained relatively constant throughout the study. The concentration of leptin was significantly higher in well-fed ewes than in under-fed ewes on Days $-21,-10$ and -5 .

\subsection{Concentrations of mammogenic and lactogenic hormones}

In both groups, there was a general decrease in the plasma concentration of progesterone, decreasing from Day -30 until lambing (Fig. 5). Well-fed ewes had lower values than under-fed ewes throughout the treatment period and the difference was significant on most occasions. On the day before lambing and during the last $12 \mathrm{~h}$ of pregnancy, the concentrations were $4.61 \mathrm{ng} . \mathrm{mL}^{-1}$ and $2.81 \mathrm{ng} . \mathrm{mL}^{-1}$ for the well-fed ewes, and $6.46 \mathrm{ng} . \mathrm{mL}^{-1}$ and $3.64 \mathrm{ng} \cdot \mathrm{mL}^{-1}$ for the under-fed ewes $(P<0.05)$. At lambing and after lambing, the under-fed ewes continued to have higher plasma concentrations of progesterone than the well-fed ewes $(P<0.05)$.

For both groups, the plasma concentrations of prolactin were either constant or gradually increased from Day -30 to Day -10 and then rose sharply during the last $2-$ 3 days of pregnancy (Fig. 5). After lambing, the values decreased but remained high compared to the early pre-partum period. Prolactin concentrations were significantly higher in well-fed ewes than in under-fed ewes for the whole period with the exception of Days $-16,-2$ and 0 .

In both groups, $\mathrm{GH}$ concentrations increased from Day -30 until one hour after birth (Fig. 6). Under-fed ewes had higher values than the well-fed ewes throughout the experimental period, but the differences were only significant on Days -5 and -3 . Insulin concentrations changed little between Days -30 and Day -1 in either group but increased markedly around lambing (Fig. 6) returning to pre-partum levels by $18 \mathrm{~h}$ after lambing. Well-fed ewes had 

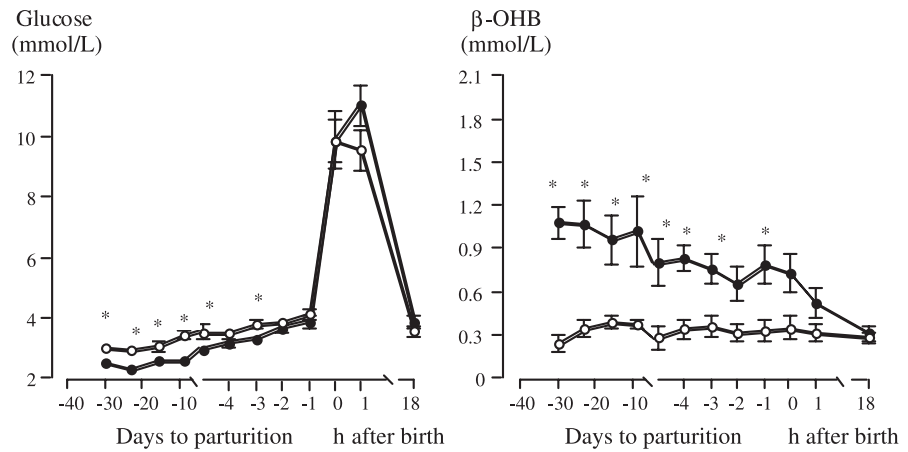

Figure 3. Plasma concentrations of glucose and $\beta$-OHB during the last 30 days of gestation in Merino ewes fed $110 \%$ (open circles) or $70 \%$ of ME requirements (closed circles) $(* P<0.05$ ).
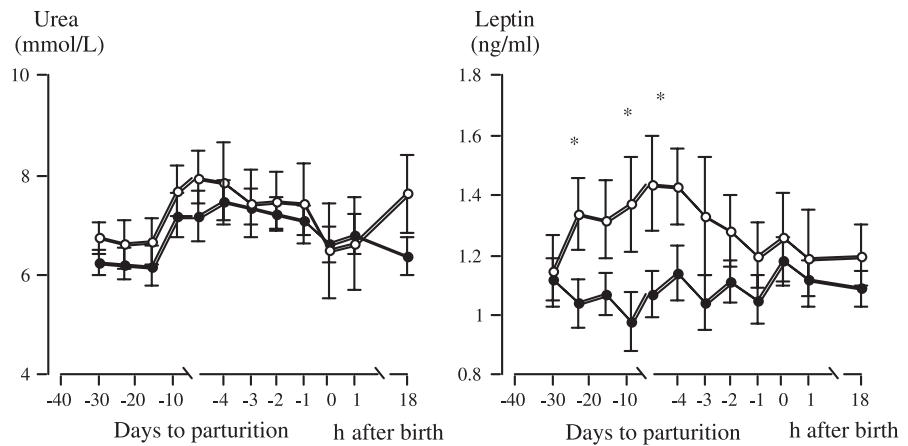

Figure 4. Plasma concentrations of urea and leptin during the last 30 days of gestation in Merino ewes fed $110 \%$ (open circles) or $70 \%$ of ME requirements (closed circles) $(* P<0.05$ ).
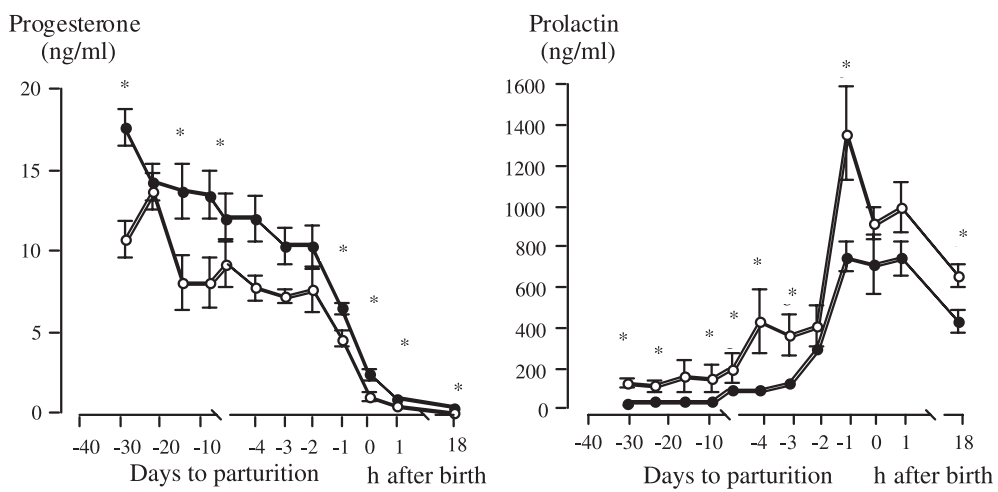

Figure 5. Plasma concentrations of progesterone and prolactin during the last 30 days of gestation in Merino ewes fed $110 \%$ (open circles) or $70 \%$ of ME requirements (closed circles) $(* P<0.05$ ). 

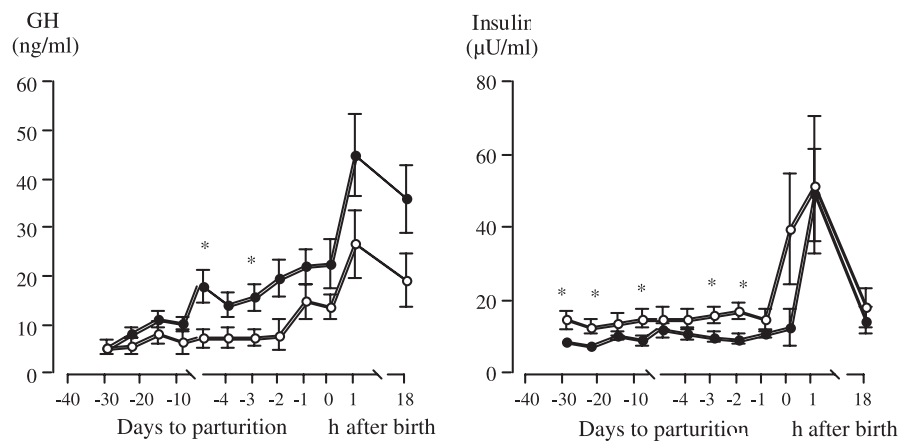

Figure 6. Plasma concentrations of GH and insulin during the last 30 days of gestation in Merino ewes fed $110 \%$ (open circles) or $70 \%$ of ME requirements (closed circles) $(* P<0.05$ ).

higher values than underfed ewes throughout the pre-partum period and the differences were significant on Days $-30,-23$, $-9,-3$ and -2 .

Plasma IGF-I concentrations were higher in well-fed ewes than in under-fed ewes throughout the experimental period $(P<0.05$; Fig. 7) and the differences were significant on all except four occasions. The pattern was similar for both treatments with generally constant levels until an increase in the last few days before birth and then a slow increase over the last prepartum observations. After lambing, IGF-I values remained higher than pre partum levels in both groups and the difference between the groups was maintained $(P<0.05)$.

The plasma concentrations of cortisol remained low in both groups until Day -3 pre-partum and then increased sharply to peak at lambing $(P<0.05$; Fig. 7$)$. Thereafter, the concentrations decreased and, by $18 \mathrm{~h}$ after lambing, they were similar to those observed 2-3 days before lambing. Well-fed ewes tended to have higher concentrations than underfed ewes during the pre-partum period but the difference was only significant on Days $-23,-3$ and -1 . The differences were not significant at and after lambing.

\section{DISCUSSION}

This experiment shows that supplying $70 \%$ of ME requirements is insufficient for adequate lactation and suggests that it results in a hormone regime that is inappropriate for optimal udder development and colostrum synthesis.

The metabolic profile of underfed ewes was characterised by lower plasma glucose and leptin levels and higher $\beta$-OHB concentrations during the pre-partum period compared with well-fed ewes. Low concentrations of glucose can limit milk secretion because glucose is a precursor for lactose synthesis. For example, in goats fasted for $24 \mathrm{~h}$, a single infusion of glucose into the mammary artery increased milk yield by $62 \%$ and milk lactose yield by $87 \%$ within 3 h [22]. Nevertheless, the lactating mammary gland of a high yielding goat uses $60-85 \%$ of the total body glucose and the correlation between milk yield and mammary uptake of glucose is about 0.93 . In our experiment, the under-fed ewes had a lower plasma concentration of glucose during the pre-partum period and this almost certainly would have slowed lactose synthesis and thus contributed to limit their production of colostrum.

Well-fed ewes had enough nutrients in their diet to maintain or slightly increase 

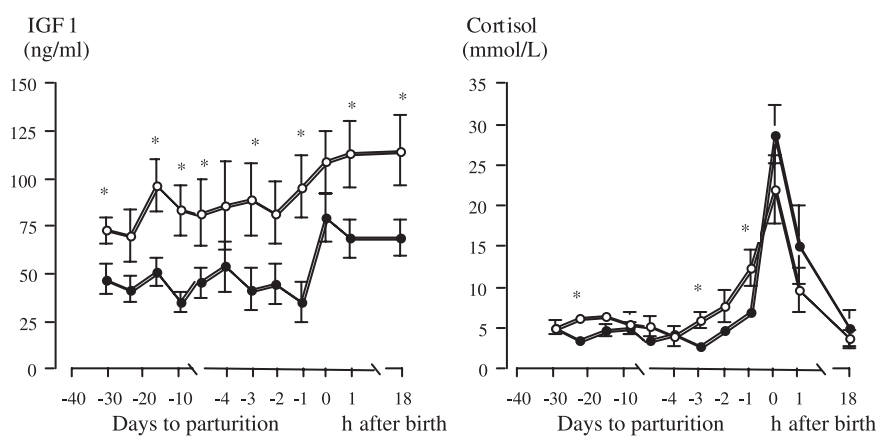

Figure 7. Plasma concentrations of IGF-I and cortisol during the last 30 days of gestation in Merino ewes fed $110 \%$ (open circles) or $70 \%$ of ME requirements (closed circles) $(* P<0.05)$.

their body condition during the last month of pregnancy. On the contrary, under-fed ewes lost body condition and this was reflected in the high plasma concentration of $\beta$-OHB in these animals [23]. The values for $\beta$-OHB in the under-fed ewes were above normal values for sheep $\left(<0.7 \mathrm{mmol} . \mathrm{mL}^{-1}\right.$ [24]) throughout the last 30 days of the pre-partum period. Some animals had values close to those that produce pregnancy toxaemia [25] although they did not show symptoms. On the contrary, in this experiment, the ewes did not need to expend energy to graze because they were fed in pens so, under field conditions, many of the underfed ewes may have had serious problems.

Plasma concentrations of leptin followed the same pattern as body condition during most of the pre-partum period, confirming previous observations in our laboratory [17]. Interestingly, during the last 5 days of pregnancy, the leptin concentrations in well-fed ewes were similar to those in the under-fed ewes. This might be because the "well-fed" ewes were temporarily undernourished at this time despite being offered a diet that was theoretically adequate to meet the ewe's ME requirements. Another possible explanation is that leptin secretion is controlled by a range of other endocrine factors, including some of those measured in the present study [26]. Thomas et al. [27], working with pregnant ewes that were moderately fed, reported similar results and attributed them to a catabolic process and fat mobilisation during late pregnancy. This could have been the case with the sheep in our experiment. When they were fed, they did not refuse food so it seems that the nutrients available, or their composition, were insufficient to cover this short and important period of high nutrient demand. As a result, they were forced to mobilise adipose tissue [23]. By contrast, plasma urea was similar in well-fed and underfed animals, suggesting that the protein requirements were met either by the diet or tissue mobilisation, or both.

The concentrations of all six lactational hormones differed between the wellfed and under-fed animals to an extent that would be likely to affect the onset of lactogenesis. In sheep, as in other mammals, lactogenesis is triggered by the withdrawal of progesterone at the end of gestation, in addition to dramatic increases in the secretion of cortisol and prolactin [28]. We observed a decrease in progesterone concentrations during the pre-partum period in both groups but the rate of decrease was related to nutrition, with under-fed ewes maintaining higher levels for longer than the well-fed ewes, most likely due to differences in the rate 
of clearance [29-31]. According to Burd et al. [32], the circulating concentration of progesterone must fall below a threshold of $10 \mathrm{ng} . \mathrm{mL}^{-1}$ for the mammary blood flow to increase and enhance the supply of metabolic substrates to the udder. It took the under-fed ewes nearly 15 days longer to fall below this level than wellfed ewes. Furthermore, by the day before lambing, in neither group, had progesterone levels fallen below the second threshold of $1 \mathrm{ng} . \mathrm{mL}^{-1}$ which is considered by Hartmann et al. [33] to be necessary for copious synthesis of colostrum. On the day before lambing, plasma concentrations of progesterone were still too high in $60 \%$ of the ewes in each group. Immediately after birth, all of the well-fed ewes had reached an appropriate level but the progesterone concentrations were still too high in $40 \%$ of under-fed ewes to allow an adequate onset of lactogenesis [2]. This probably explains why more than $60 \%$ of the underfed ewes did not have enough colostrum to meet the immediate requirements of their new-born lamb. The high concentration of progesterone in the under-fed ewes probably resulted in the concentration of lactose being low and consequently these ewes produced a low volume of colostrum. Progesterone inhibits $\alpha$-lactalbumin, one of the proteins required for the synthesis of lactose synthetase, the rate-limiting enzyme for lactose synthesis. Since lactose osmotically draws water into the mammary secretory epithelium $[34,35]$, any delay in lactose synthesis would limit the production of colostrum. In addition, the colostrum that is produced would have a high viscosity and therefore be difficult for the lambs to suck [36,37].

The nutrition of the ewes may also have contributed to the observed differences in plasma prolactin concentrations, which is another factor controlling lactogenesis. Well-fed ewes had higher levels of prolactin than under-fed ewes throughout the final 30 days pre-partum. Prolactin enhances the rate of synthesis of casein and $\alpha$-lactalbumin when prolactin receptors are present in mammary tissue. Prolactin upregulates its own receptors so, each increase in prolactin concentration leads to an increase in the responsiveness of mammary tissue to the hormone [38]. However, the production of prolactin receptors is inhibited by high levels of progesterone and prolactin binding can only increase after progesterone concentrations decline at the end of gestation.

The circulating concentrations of cortisol were slightly affected by the level of nutrition, and this might be linked to the tendency for well-fed ewes to produce bigger fetuses. On the contrary, the levels of GH were much higher in the under-fed than in the well-fed ewes. Normally, GH promotes udder development and galactopoiesis through IGF-I [39]. However, in the cow, when the nutritional status is severely compromised by a short-term fast, the basal concentrations of IGF-I are lower and the ability of GH to increase IGF-I secretion is inhibited. This concurs with the present experiment in which underfed ewes had lower concentrations of IGF-I than well-fed ewes. At the same time, insulin concentrations in the underfed ewes were also lower than in the wellfed ewes. High circulating concentrations of insulin can increase IGF-I secretion [40] and insulin plays a similar role to IGF-I in the differentiation and development of the mammary gland [41]. Thus, the low levels of insulin or IGF-I (or both) probably explain the poor udder growth in the underfed ewes, although it is difficult to estimate how much this affected lactation in the present experiment.

The present experiment was not designed to measure lamb mortality, but the data for colostrum production suggests that more than $60 \%$ of the underfed ewes did not have enough colostrum to meet the requirements of their lambs. Under-fed ewes accumulated only $170 \mathrm{~mL}$ of colostrum 
prior to lambing and secreted $43 \mathrm{~g}$ per hour from birth until $10 \mathrm{~h}$ post partum. These values extrapolate to a mean of about $190 \mathrm{~mL}$ per kilogram of birth weight that would be available for the first $18 \mathrm{~h}$ after lambing. This is about $10 \%$ below the lambs' requirements for a minimum of about $210 \mathrm{~mL}$ per kilogram of live weight during the $18 \mathrm{~h}$ after birth under ideal conditions at lambing [42]. By contrast, the well-fed ewes produced an estimated $270 \mathrm{~mL}$ per kilogram of birth weight, enough for the lamb even under cold weather conditions when the demand for colostrum would be higher [36].

In addition to its consequences on the physiology of the lamb, limitation of colostrum production is also likely to impair filial attachment (see Nowak, this issue).

The physiological and behavioural consequences of poor colostrum production following undernutrition, are likely to be even more acute in the case of twin births, and this could explain part of the much higher early mortality often reported in twins [43].

\section{REFERENCES}

[1] Mellor DJ, Murray L. Effects of maternal nutrition on udder development during late pregnancy and on colostrum production in Scottish Blackface ewes with twin lambs. Res Vet Sci 1985, 39: 230-234.

[2] Mellor DJ, Flint DJ, Vernon RG, Forsyth IA. Relationships between plasma hormone concentrations, udder development and the production of early mammary secretions in twin-bearing ewes on different planes of nutrition. Q J Exp Physiol 1987, 72: 345-356.

[3] Annison EF. Fat deposition in ruminants in: Farrel D.J. (Ed.), Recent Advance in a Animal Nutrition in Australia, The University of New England Publishing Unit; Armidale 1993, pp. 51-60.

[4] Banchero GE, Quintans G, Martin GB, Lindsay DR, Milton JTB. Production of colostrum by Polwarth ewes grazing Lucerne pastures: effect of birth type and body condition. Proceedings of IX World Conference on Animal Production, Porto Alegre, Brasil, October 26-31 2003, pp 221.

[5] Oddy VH, Holst PJ. Maternal-foetal adaptation to mid pregnancy feed restriction in single-bearing ewes. Aust J Agri Res 1991, 42: 969-978.

[6] Hamudikuwanda H, Gallo G, Block E, Downey BR. Adipose tissue progesterone concentrations in dairy cows during late pregnancy and early lactation. Anim Reprod Sci 1996, 43: 15-23.

[7] MAFF, Ministry of Agriculture, Fisheries and Food. Energy Allowances and Feeding Systems for Ruminants. Technical Bulletin 33, London, 1975, 79 p.

[8] Bencini R, Purvis IW. The yield and composition of milk from Merino sheep. Proceedings of the Australian Society of Animal Production 1990, 18: 144-147.

[9] McMurray $\mathrm{CH}$, Blanchflower WJ, Rice DA. Automated kinetic method for D-3hydroxybutirate in plasma or serum. Clin Chem 1984, 30: 421-425.

[10] Gales NJ, Williamson P, Higgins LV, Blackberry MA, James I. Evidence for a prolonged postimplantation period in the Australian sea lion (Neophoca cinerea). J Reprod Fertil 1997, 111: 159-163.

[11] Abraham GE, Odell WD, Swerdloff RS, Hopper K. Simultaneous radioimmunoassay of plasma FSH, LH, progesterone, 17hydroxyprogesterone and estradiol-17beta during the menstrual cycle. J Clin Endocrinol 1972, 34: 312-318.

[12] Hales CN, Randle PJ. Immunoassay of insulin with insulin-antibody precipitate. Biochem J 1963, 88: 137-146.

[13] Basset JM, Wallace ALC. Diluents for insulin standards in immunoassay of insulin in undiluted ovine plasma by double antibody technique. J Endocrinol 1966, 36: 99-100.

[14] Tindal JS, Knaggs GS, Hart IC, Blake LA. Release of growth hormone in lactating and non-lactating goats in relation to behaviour, stage of sleep, electroencephalographs, environmental stimuli and levels of prolactin, insulin, glucose and free fatty acids in the circulation. J Endocrinol 1978, 76: 333-346.

[15] Downing JA, Joss J, Connell P, Scaramuzzi RJ. Ovulation rate and the concentrations of gonadotrophic and metabolic hormones in ewes fed lupin grain. J Reprod Fertil 1995, 103: 137-145. 
[16] Gluckman PD, Johnson-Barret JJ, Butler JH, Edgar BW, Gunn TR. Studies on insulin-like growth factor-I and -II by specific radioligand assays in umbilical cord blood. Clin Endocrinol 1983, 19: 405-413.

[17] Blache D, Tellam RL, Chagas LM, Blackberry MA, Vercoe PE, Martin GB. Level of nutrition affects leptin concentrations in plasma and cerebrospinal fluid in sheep. J Endocrinol 2000, 165: 625-637.

[18] Mellor DJ, Murray L. Making the most of colostrum at lambing. Vet Rec 1986, 118: 351-353.

[19] Abacus Concepts. Super ANOVA. Abacus Concepts, Inc, Berkeley, CA, 1989, pp 320.

[20] Genstat. Genstat 5, release 3, Reference manual. Clarendon Press, New York, 1993.

[21] Russell AJF, Doney JM, Gunn RG. Subjective assessment of body fat in live sheep. J Agri Sci 1969, 72: 451-454.

[22] Linzell JL. The effect of infusions of glucose, acetate and amino acids on hourly milk yield in fed, fasted and insulin-treated goats. J Physiol 1967, 190: 347-357.

[23] Treacher TT. Effects of nutrition in late pregnancy on subsequent milk production in ewes. AnimProd 1970, 12: 23-36.

[24] Aiello, S.E. Serum biochemical reference range in: Aiello SE (Eds.), The Merck Veterinary Manual, Merck \& Co., Inc, Whitehouse Station, Philadelphia, 1998, pp 2192-2193.

[25] Aiello, S.E. Metabolic disorders in: Aiello SE (Eds.), The Merck Veterinary Manual, Merck \& Co., Inc, Whitehouse Station, Philadelphia, 1998, pp 723-747.

[26] Chilliard Y, Delavaud C, Bonnet M. Leptin expression in ruminants: nutritional and physiological regulations in relation with energy metabolism. Domest Anim Endocrinol 2005, 29: 3-22.

[27] Thomas L, Wallace JM, Aitken RP, Mercer, JG, Trayhurn P, Hoggard N. Circulating leptin during ovine pregnancy in relation to maternal nutrition, body composition and pregnancy outcome. J Endocrinol 2001, 169: 465-476.

[28] Delouis C. Physiology of colostrum production. Annal Rech Vet 1978, 9: 193-203.

[29] Brockhus MA, Nunan K, Parr RA. A relationship between nutrition and progesterone at parturition and the implication for lamb survival. Austral Soc Reprod Biol 1988, 20: 62 .
[30] Williams AH, Cumming IA. Inverse relationship between concentration of progesterone and nutrition in ewes. J Agric Sci 1982, 98: 517-522.

[31] Parr RA. Nutrition-progesterone interactions during early pregnancy in sheep. Reprod, Fertil Develop 1992, 4: 297-300.

[32] Burd LI, Takahashi K, Ward K, Ascherman G, Dowers S, Scommegna, A. The relationship of changes in mammary blood flow and plasma progesterone at the time of parturition in the ewe. Am J Obst Gynecol 1978, 132: 385-391.

[33] Hartmann PE, Trevethan P, Shelton JN. Progesterone and oestrogen and the initiation of lactation in ewes. J Endocrinol 1973, 59: 249-259.

[34] Linzell JL, Peaker M. Mechanisms of milk secretion. Physiol Rev 1971, 51: 564-597.

[35] Leong WS, Navaratnam N, Stankiewicz MJ, Wallace AV, Ward S, Kuhn N. Subcellular compartmentation in the synthesis of the milk sugars lactose and -2,3-sialyllactose. Protoplasm 1990, 159: 144-156.

[36] McCance I, Alexander G. The onset of lactation in the Merino ewe and its modification by nutritional factors. Aust J Agric Res 1959, 10: 699-719.

[37] Holst PJ, Hall DG, Allan CJ. Ewe colostrum and subsequent lamb suckling behaviour. Aust J Exp Agri 1996, 36: 637-640.

[38] Tucker HA. General endocrinological control of lactation in: Lactation, L.L. Larson and Smith, V. R. (Eds.), Academic Press, New York \& London, 1974, Vol 1, pp 277326.

[39] Bauman DE, Vernon RG., Effects of exogenous bovine somatotropin on lactation. Annual Rev Nut 1993, 13: 437-461.

[40] Bequette BJ, Kyle CE, Crompton CE, Buchan V, Hanigan MD. Insulin regulated milk production and mammary gland and hind-leg amino acids fluxes and blood flow in lactating goats. J Dairy Sci 2001, 84: 241255.

[41] Kacsoh B. Reproductive endocrinology in: J. Dolan (Ed.), Endocrine Physiology, McGraw-Hill, New York, 2000, pp 448-639.

[42] Mellor DJ, Cockburn F. A comparison of energy metabolism in the new-born infant, piglet and lamb. Q J Exp Physiol 1986, 71: 361-379.

[43] Alexander G, Davies HL. Relationship of milk production to number of lambs born or suckled. Aust J Agri Res 1959, 10: 720-724. 